Hispania, 2021, vol. LXXXI, n. ${ }^{\circ}$ 269, septiembre-diciembre, págs. 591-619 ISSN: 0018-2141, e-ISSN: 1988-8368, https://doi.org/10.3989/hispania.2021.014

\title{
Violencia, saqueos y abusos de poder. La problemática en torno a las últimas voluntades de don Pedro Girón, maestre de la Orden de Calatrava (1466-1496)"
}

\author{
Óscar López Gómez ${ }^{1}$ \\ Universidad de Castilla-La Mancha \\ oscar.lopezgomez@uclm.es
}

RESUMEN: Don Pedro Girón, maestre de la Orden de Calatrava entre 1445 y 1466 , fue uno de los personajes más controvertidos de la Castilla del siglo $\mathrm{XV}$, tanto por su supuesta actitud despiadada, como, sobre todo, por seguir los pasos de su hermano, el sibilino marqués de Villena, don Juan Pacheco. En este trabajo se analizan las repercusiones que tuvo una de las mandas que el maestre dejó instituidas en su testamento, en la que requería que, en su nombre, por el bien de su alma y en exoneración de su conciencia, se indemnizase a las víctimas de sus robos y sus abusos de poder. Su hijo y heredero, Juan Téllez Girón, el segundo conde de Urueña, hubo de afrontar durante décadas la obligación de resarcimiento que su padre habia establecido, hasta que, definitivamente, decidió requerir la ayuda de uno de los grandes juristas al servicio del papa, Giovanni Battista Caccialupi, que le ofreció una solución legal y teológica, que, por fin, le permitiría librarse del desagravio requerido.

\footnotetext{
* Este trabajo forma parte de los resultados del proyecto de investigación «Ciudad, economía y territorio en Castilla-La Mancha durante la Baja Edad Media», referencia SBPLY/19/180501/000187 (años 2020-2023), financiado por la Junta de Comunidades de Castilla-La Mancha.

Siglas de archivos: Archivo General de Simancas, Simancas, Valladolid (AGS), sección Registro General del Sello (RGS); Archivo Histórico de la Nobleza, Toledo (AHN); Archivo de la Real Chancillería de Valladolid, Valladolid (ARChV); y Real Academia de la Historia, Madrid (RAH), Colección Salazar y Castro (CSC). Gran parte de los documentos de archivo que se emplean en este trabajo están digitalizados en PARES, Portal de Archivos Españoles. Al lado de la referencia se señala la imagen digital a consultar. Cuando el texto no está digitalizado así se indica (no dig.).

${ }^{1}$ ORCID iD: https://orcid.org/0000-0002-9847-7178
}

Copyright: (C) 2021 CSIC. Este es un artículo de acceso abierto distribuido bajo los términos de una licencia de uso y distribución Creative Commons Reconocimiento 4.0 Internacional (CC-BY 4.0) 


\section{Palabras clave: Orden de Calatrava; Pedro Girón; violencia; siglo XV; abusos de poder; Giovanni Battista Caccia- lupi.}

Violence, pillaging and abuse of power. The issues surrounding the last will and testament of Pedro Girón, Master of the Order of Calatrava (1466-1496)

ABSTRACT: Don Pedro Girón, Master of the Order of Calatrava from 1445 to 1466, was one of the most controversial figures in fifteenth-century Castile, both because of his allegedly ruthless arrogance and his compliant attitude towards his brother, the ruthless Marquis of Villena, Don Juan Pacheco. This paper analyses the repercussions of one of the commands he left in his will, compensating victims of his pillaging and abuse of power, for the good of his soul and to assuage his conscience. The Master's heir, his son Juan Téllez Girón, second count of Urueña, had to struggle for three decades with the obligation to pay what his father had established. Finally, he decided to seek help from one of the pope's greatest jurists, Giovanni Battista Caccialupi, who offered a legal and theological solution.

KeY words: Order of Calatrava; Pedro Girón; violence; fifteenth century; abuse of power; Giovanni Battista Caccialupi.

CÓMO CITAR ESTE ARTÍCULO / CITATION: López Gómez, Óscar, «Violencia, saqueos y abusos de poder. La problemática en torno a las últimas voluntades de don Pedro Girón, maestre de la Orden de Calatrava (1466-1496)», Hispania, 81/269 (Madrid, 2021): 591-619. https://doi.org/10.3989/hispania.2021.014.

Pedro Girón es una de las figuras más fascinantes de la historia política del siglo XV en Castilla. Cómplice de su hermano, el astuto y sibilino marqués de Villena, Juan Pacheco, alcanzó la dignidad de maestre de la Orden de Calatrava con menos de 25 años, favoreciendo que se generase en torno a él una abundancia de noticias sobre sus acciones de armas, sus intrigas palaciegas y sus logros, que hace que hoy resulte relativamente fácil reconstruir las vicisitudes por los que discurrió su existencia ${ }^{2}$. La imagen que a menudo se ha ofrecido de Girón, sin embargo, siempre ha sido ominosa; en sintonía, de algún modo, con lo que escribieron de él los cronistas que trabajaban para los reyes, que nunca le perdonaron su modo de actuar en los reinados de Juan II y Enrique IV, hasta el punto de erigirlo en paradigma de hombre «falto de escrúpulos, de insaciable ambición y de amoralidad bien manifiesta»3. Uno de sus mejores biógrafos actuales, el lamentablemente

${ }^{2}$ UHAGON, 1898. CABRERA, 1989. AGUADO GONZÁLEZ, 1991, vol. 1: 67-188. ATIENZA HERNÁNDEZ, 1987. FRANCO SILVA, 1995. O'CALLAGHAN, 1961. TORRESFONTES SUÁREZ, 1977. VIÑA BRITO, 1989; 1990. MADRID y MEDINA, 2004.

3 TORRES-FONTES SUÁREZ, 1977: 45. 
fallecido Alfonso Franco Silva, aseveraba que los dos hermanos, «el marqués» y «el maestre», hacían una combinación perfecta. El primero, Juan Pacheco, era «un hombre extraordinariamente hábil, astuto e inteligente, dotado de cualidades políticas innegables para la intriga, el pacto y la seducción, sin importarle jamás la palabra dada, el juramento o la amistad». Girón, por su parte, «hombre de acción, violento y brutal», no tenía ningún problema en sembrar el caos, si era preciso. «Uno era el cerebro, el otro el brazo militar», concluía Franco Silva ${ }^{4}$.

Las páginas que siguen no buscan ofrecer una imagen diferente del personaje. Su objetivo es mucho más humilde: tan solo aclarar la problemática surgida tras la defunción del maestre por culpa de los desafueros que había perpetrado, basándonos para ello en la documentación de archivo que se conserva ${ }^{5}$. Vaya por delante, eso sí, como muestra de honestidad intelectual, que, en consonancia con lo señalado por otros historiadores, creo que, por más que se haya insistido en la actitud despiadada y salvaje de Girón, capaz de recurrir a cualquier método para imponer sus posturas, lo que sabemos de él no puede considerarse definitorio en su personalidad, ya que «no contamos con elementos de juicio suficientes para plasmar una visión objetiva» ${ }^{6}$. Como ha apuntado Manuel Ciudad Ruiz, su manera de proceder no fue «distinta a la de la mayoría de los miembros de la nobleza de la época, ni muchas de sus acciones políticas tan insólitamente contra derecho como nos han transmitido algunos cronistas $\rangle^{7}$. El problema es que a Pedro Girón sus rivales no le

${ }^{4}$ FRANCO SILVA, 2011: 27-28, 104.

5 El núcleo documental del presente trabajo lo constituyen los fondos del Archivo General de Simancas, en especial la sección Registro General del Sello y, sobre todo, del Archivo de la Nobleza, sección Frías, donde se guarda todo tipo de documentación sobre algunos de los principales linajes de Castilla: desde cuestiones relacionadas con sus propiedades y cargos públicos a todo lo referente a sus vinculaciones políticas, alianzas matrimoniales, testamentos y, en general, a la gestión de su enorme poder. Este tipo de documentos complementa y matiza muchas de las informaciones que pueden leerse en ese otro núcleo de información cardinal a la hora de acercarse a los nobles que son las crónicas de la monarquía. En el caso de Pedro Girón, las crónicas básicas a la hora de conocer los avatares de su vida, hasta 1466, son tanto las crónicas de Juan II: obra de Fernán Pérez de Guzmán («Crónica del rey don Juan Segundo de Castilla y León», en Crónicas de los Reyes de Castilla, Madrid, BAE, 1953, vol. LXVIII), de Pero Carrillo de Huete (Crónica del Halconero de Juan II, edición de Juan de Mata Carriazo, Madrid, Espasa-Calpe, 1946) y de Lope de Barrientos (Refundición de la crónica del Halconero de Juan II, edición de Juan de Mata Carriazo, Madrid, Espasa-Calpe, 1946); como las crónicas de Enrique IV, realizadas por Alonso de Palencia (Crónica de Enrique IV, Madrid, Atlas, 1975), Diego Enríquez del Castillo (Crónica de Enrique IV, edición de Aurelio Sánchez Martín, Valladolid, Universidad de Valladolid, 1994) y Lorenzo Galíndez de Carvajal (Crónica de Enrique IV, edición de Juan Torres Fontes, Murcia, CSIC, 1946).

6 AGUADO GONZÁLEZ, 1991: 163. FRANCO SILVA, 2011: 289-291.

7 CIUDAD RUIZ, 2000: 322-323. O'CALLAGHAN, 1961: 389. 
toleraron su proximidad a su hermano, ni su acceso meteórico a la dignidad de maestre, ni su traición al rey Enrique IV — al que tan afín se había mostrado en la década de 1440 - ni, sobre todo, la osadía de querer convertirse en el marido de la princesa Isabel, lo que de haberse llevado a efecto le habría permitido coronarse rey de Castilla ${ }^{8}$.

Los documentos en que se basa este estudio hablan de arbitrariedades y violencia, $y$, de algún modo, vienen a corroborar la imagen fatídica del maestre de Calatrava que se ha venido perfilando desde el siglo XV, propia de un caudillo sin escrúpulos, dispuesto a emplear la fuerza física y a recurrir a su inmenso poder en virtud de sus fines, sin ninguna clase de cortapisa moral ${ }^{9}$. Sin embargo, los atropellos no eran exclusivos de Pedro Girón; y ni siquiera de la alta nobleza. Como ha venido recalcando la historiografía en los últimos tiempos, los caballeros también recurrían en las ciudades a la extorsión y los crímenes a la hora de amparar sus intereses ${ }^{10}$. Por otra parte, de ningún modo se trataba de un hombre «simple». Tal vez Juan Pacheco fuese «más despierto, más inteligente $\mathrm{y}$, por supuesto, más hábil $»^{11}$, pero Girón no actuaba como un burdo ejecutor de órdenes, sin ideas y en absoluta dependencia de su hermano. Por contra, tuvo templanza para desempeñar el papel que le correspondía como segundón de su linaje. De un linaje humilde de la pequeña nobleza, en el que por edad el líder era Juan Pacheco. Y se aprovechó con astucia de su poder al frente de la orden de los calatravos ${ }^{12}$.

Más allá de esto, al margen de la personalidad que realmente tuviera Pedro Girón, una de las cuestiones que le hacen extraordinario es lo que ocurrió después de su muerte, dada la solicitud que hizo a sus albaceas y herederos para que subsanaran los perjuicios y las arbitrariedades que había cometido. Aunque no se trataba de una cláusula inusual en los testamentos de los nobles ${ }^{13}$, o bien tenía un sentido simbólico, y no se llevaba a la práctica, o bien, de ejecutarse, se hacía de manera suigéneris, sin repercusiones de calado y sin dejar huellas documentales. En lo referente a Girón, en cambio, existen numerosos escritos sobre el asunto, que hacen que muerto, esfumado de las páginas de las crónicas, el personaje cobre vida una y otra vez en la documentación de archivo a lo largo de treinta años.

8 TORRES-FONTES SUÁREZ, 1977: 46. O'CALLAGHAN, 1961: 389.

${ }^{9}$ Con una actitud cercana a la de un «malhechor feudal»: MORETA VELAYOS, 1978.

${ }^{10}$ La bibliografía al respecto es ingente. Sirvan a modo de ejemplo algunas aportaciones novedosas de los últimos años: NARBONA VIZCAÍNO, 2003. SOLÓRZANO TELECHEA, 2005. MONSALVO ANTÓN, 2009; 2016. LÓPEZ GÓMEZ, 2015. DIAGO HERNANDO, 2016. JARA FUENTE, 2019. FERNÁNDEZ DE LARREA Y ROJAS, 2019.

11 FRANCO SILVA, 2011: 54.

12 VAL VALDIVIESO, 1976: 169.

13 OTERO PIÑEYRO MASEDA y GARCÍA-FERNÁNDEZ, 2013: 141-142. 


\section{LA CARGA ECONÓMICA DEL TESTAMENTO DEL MAESTRE}

En 1459 el papa Pío II autorizó al maestre de Calatrava a hacer testamento en favor de sus hijos, que eran todos bastardos, ya que por su estatus guerrero y religioso Girón no había podido casarse $\mathrm{e}^{14}$. Aun así, como era un hombre sano y relativamente joven, de 36 años, no testó de manera inmediata, sino mucho después, el 28 de abril de $1466^{15}$, ante la inminencia de una muerte prematura - tal vez por envenenamiento-, que tuvo lugar cuatro días más tarde, el 2 de mayo, y que, según sus opositores, se produjo entre blasfemias, culpando a Dios por no prolongar «su vida de cuarenta y tres años» justo en ese momento, a las puertas de su polémica boda con la princesa Isabel, en el culmen de su carrera política.

El testamento del maestre fue estudiado en 1988 por Ana Viña Brito ${ }^{16}$. Se adaptó de forma modélica a los cánones establecidos en cuanto a su estructura, dividiéndose en treinta y tres mandas, repartidas en cuatro bloques: asuntos protocolarios y de carácter espiritual en torno al enterramiento; cuestiones de naturaleza económica - pago de deudas, resarcimiento de daños, liberación de cautivos, beneficios a servidores e instituciones -; reparto del patrimonio entre descendientes; y, por último, nombramiento de albaceas. En conjunto, dejando al lado las cuestiones espirituales y la herencia propiamente dicha, el impacto económico inminente del testamento, es decir, lo que Pedro Girón determinó que se gastase de su hacienda de forma más o menos perentoria, superaba los cinco millones de maravedíes. Ciertas mandas eran económicamente imprecisas, pero en muchas de ellas la cantidad de dinero a sufragar estaba perfectamente tasada.

La disposición financiera más importante, para «facer algún bien e remuneración» a sus servidores, ascendería a 3.624 .000 maravedíes, beneficiando a 183 hombres. Estos sujetos eran su clientela directa: quienes le habían acompañado en toda clase de peripecias políticas y militares, operaciones de expolio y abusos de poder.

${ }_{14}$ AHN, Osuna, caja 1, docs. 48-51 y 56-60 y carpeta 60, docs. 3, 5, 6, 7.

15 Varias copias: AHN, Frías, caja 307, doc. 46. AHN, Osuna, caja 2047, docs. 32-33 y caja 2, docs. 32-33. RAH, CSC, M-104, ff. 11r-17v (no dig.). UHAGÓN, 1898, doc. IX: 84-94. VIÑA BRITO, 1989.

16 VIÑA BRITO, 1988: 188-192; 1989. 


\section{Cuadro 1}

\begin{tabular}{|c|c|c|c|c|c|}
\hline \multicolumn{3}{|c|}{$\begin{array}{l}\text { SERVIDORES Y CRIADOS } \\
\text { DE DON PEDRO GIRÓN }\end{array}$} & \multicolumn{3}{|c|}{$\begin{array}{c}\text { BENEFICIARIOS } \\
\text { SEGÚN MARAVEDÍES. }\end{array}$} \\
\hline Oficio & Servidores & $\begin{array}{c}\text { Cantidad global de maravedíes } \\
\text { que reciben }\end{array}$ & Mrs. & Servidores & Total \\
\hline Alcaide & 9 & 360.000 [entre 100.000 y 5.000$]$ & 200.000 & 1 & 200.000 \\
\hline Alcalde mayor & 1 & 20.000 & 100.000 & 6 & 600.000 \\
\hline Alguacil & 4 & 55.000 [entre 15.000 y 10.000 ] & 80.000 & 3 & 240.000 \\
\hline \multicolumn{2}{|c|}{ Ama de su hijo don Alfonso } & 30.000 & 70.000 & 1 & 70.000 \\
\hline Aposentador & 2 & $35.000[20.000$ y 15.000$]$ & 60.000 & 1 & 60.000 \\
\hline Ayo & 1 & 20.000 & 50.000 & 11 & 550.000 \\
\hline Ayudante de cocina & 1 & 15.000 & 40.000 & 5 & 200.000 \\
\hline Ballestero & 6 & $13.000[2.000$ y uno 3.000$]$ & 30.000 & 12 & 360.000 \\
\hline Barbero & 2 & $6.000[4.000$ y 2.000$]$ & 25.000 & 1 & 25.000 \\
\hline Canciller & 1 & 200.000 & 20.000 & 26 & 520.000 \\
\hline Carnicero & 1 & 10.000 & 15.000 & 18 & 270.000 \\
\hline Cazador & 1 & 10.000 & 10.000 & 24 & 240.000 \\
\hline Cocinero & 2 & 80.000 [40.000 cada uno] & 8.000 & 4 & 32.000 \\
\hline Comendador & 5 & 270.000 [de 100.000 a 20.000$]$ & 7.000 & 2 & 14.000 \\
\hline Confitero & 1 & 10.000 & 6.000 & 2 & 12.000 \\
\hline Contador & 2 & $40.000[30.000$ y 10.000$]$ & 5.000 & 20 & 100.000 \\
\hline Copero & 1 & 1.000 & 4.000 & 12 & 48.000 \\
\hline Criado & 2 & $70.000[50.000$ y 20.000$]$ & 3.000 & 16 & 48.000 \\
\hline Despensero & 1 & 100.000 & 2.000 & 17 & 34.000 \\
\hline Espingardero & 3 & $12.000[5.000$ y uno 2.000$]$ & 1.000 & 1 & 1.000 \\
\hline Lombardero & 3 & $10.000[3.000$ y uno 4.000$]$ & Total & 183 & 3.624 .000 \\
\hline Maestresala & 1 & 80.000 & & & \\
\hline Mayordomo & 1 & 4.000 & & & \\
\hline Montero & 1 & 2.000 & & & \\
\hline Mozo de caballos & 1 & 8.000 & & & \\
\hline Mozo de cámara & 1 & 4.000 & & & \\
\hline Mozo de espuelas & 2 & $14.000[10.000$ y 4.000$]$ & & & \\
\hline Oficial del canciller & 1 & 20.000 & & & \\
\hline Paje & 13 & 97.000 [entre 30.000 y 2.000$]$ & & & \\
\hline Platero & 1 & 20.000 & & & \\
\hline Portero & 1 & 5.000 & & & \\
\hline Prior & 2 & 10.000 [5.000 a cada uno] & & & \\
\hline \multicolumn{2}{|c|}{ Prior y frailes de Calatrava } & 30.000 & & & \\
\hline $\begin{array}{l}\text { Repostero de } \\
\text { estrados }\end{array}$ & 1 & 5.000 & & & \\
\hline Repostero de plata & 2 & $35.000[20.000$ y 15.000$]$ & & & \\
\hline Sastre & 1 & 10.000 & & & \\
\hline Secretario & 1 & 80.000 & & & \\
\hline Teniente & 2 & 70.000 [50.000 y 20.000$]$ & & & \\
\hline Trompeta & 2 & 10.000 [5.000 a cada uno] & & & \\
\hline \multicolumn{2}{|c|}{ «Vizcaíno de mi cámara» } & 3.000 & & & \\
\hline No se sabe oficio & 97 & 1.750 .000 [de 100.000 a 2.000$]$ & & & \\
\hline Total & 183 & $\begin{array}{r}3.624 .000 \\
\end{array}$ & & & \\
\hline
\end{tabular}


Al margen de este pago colectivo, a su hijo primogénito, Alfonso, el testamento le entregaba un mayorazgo formidable, con decenas de villas y rentas repartidas por Castilla y Andalucía, y el título de conde de Urueña. Para el segundón, Rodrigo, su padre había logrado una bula de la Santa Sede que le autorizaba a traspasarle la dignidad de maestre, a pesar de la protesta de algunos sectores de la Orden ${ }^{17}$. El peor parado era el tercer hijo, Juan ${ }^{18}$, para el que exclusivamente se establecía lo que le correspondiera de los bienes de libre disposición; si bien, a la postre, la defunción de Alfonso, en 1469, haría que todo el patrimonio paterno terminara en sus manos, erigiéndose en segundo conde de Urueña. Por último, a su hija María le dejó el mayor capital recogido en el testamento ${ }^{19}: 6.000$ florines de oro del cuño de Aragón, como dote para su matrimonio —unos 618.000 maravedíes, según Viña Brito ${ }^{20}$ -

Como solía ser frecuente en los testamentos nobiliarios, Girón también solicitó que, aparte de gastar hasta 200.000 maravedíes en reparaciones de castillos y de templos de su Orden, se empleasen 300.000 en la liberación de cautivos en «tierra de moros», y una cantidad idéntica, otros 300.000, para reparar los menoscabos de los que era responsable, producidos en «guerras e debates e movimientos [...] desde el año que pasó de mill e quatroçientos e quarenta». Una cantidad estándar, sobre cuya precisión tal vez no se había reflexionado lo suficiente.

En efecto, dada la enormidad del asunto al que se tenía que hacer frente, veinticinco años de guerras y de violencia, la concreción de 300.000 maravedíes para resarcir daños y perjuicios parecía una suma excesivamente baja, si de verdad el deseo del maestre era recompensar a todas las víctimas de sus arbitrariedades: ni

17 CIUDAD RUIZ, 2000: 323.

${ }^{18}$ Recogiendo un testimonio del cronista Alonso de Palencia, Cristina Torres-Fontes Suárez señala que Rodrigo y Juan eran mellizos tan similares «que cuando habitaban en la misma casa, hasta sus criados los confundían»: TORRES-FONTES SUÁREZ, 1977: 46-47.

${ }^{19}$ Los varones eran hijos bastardos de la noble sevillana Isabel de las Casas. Girón, como maestre de una orden militar, tenía el voto de castidad. No obstante, su descendencia había sido legitimada por el papa. Existe una carta de legitimación de otro hijo, llamado Diego (AHN, Osuna, caja 1, docs. 52 y 53; y carpeta 60, doc. 4), pero todos los autores coinciden en considerar que se trata de un error. Aunque PORRO (1963) lo identifica con Alfonso, UHAGÓN (1989) y O'CALLAGHAN (1961) indican que se refiere a Juan, ya que hay documentación con idéntica fecha sobre él: AHN, Frías, caja 1513, doc. 12; Osuna, caja 1, docs. 54-55. De María, sin embargo, existen dudas sobre si era hija de Isabel de las Casas o de Inés [de] Meneses, con la que Girón había tenido otra hija, Inés Girón, a la que no hizo referencia en sus últimas voluntades. Inés fue dama de Isabel la Católica, y muchos años después del fallecimiento del maestre, viuda y enferma, y sin hijos de su esposo Francisco Enríquez, señor de Vega de Ruiponce, también haría su testamento, el 29 de diciembre de 1493, en el monasterio de Santa Isabel de los Ángeles, en Córdoba: AHN, Osuna, caja 3, doc. 71; RAH, CSC, M-3, ff. 144 a 151 $\mathrm{v}$ (no dig.).

20 VIÑA BRITO, 1989: 497. 
siquiera el $6 \%$ de los gastos directos recogidos en su testamento. Tal vez nadie había calculado lo que podría conllevar el desagravio de sus atropellos e injusticias, debido, probablemente, a los apuros con que se ajustaron sus últimas voluntades, dada la premura de las circunstancias, por la enfermedad inesperada que terminaría con su vida. O quizá, como era común, la cláusula de resarcimiento de perjuicios se determinó de forma simbólica, estimando que no iba a ejecutarse. Por ejemplo, cuando el marqués de Villena testó el 27 de diciembre de 1470 - volvería a hacerlo en febrero de 1472 - , aun dejando también 300.000 maravedíes para liberar cautivos, dispuso el doble, 600.000, para resarcimiento del menoscabo que había producido ${ }^{21}$; si bien no hay textos que acrediten que tal disposición fuera consumada. No ocurrió lo mismo en el caso de Girón.

El maestre de Calatrava nombró a cuatro testamentarios. Dos laicos: su hermano y su canciller, Enrique de Figueredo. Y dos monjes jerónimos: fray Alfonso de Oropesa, general del monasterio de San Bartolomé de Lupiana, y el doctor fray Alfonso de Mesa, prior del monasterio de Santa María de la Sisla, próximo a Toledo. Si en lo relativo a Juan Pacheco y a Figueredo la designación era obvia, dada su proximidad al testador, en la de los religiosos su nombramiento tampoco sería casual. Girón, en consonancia con buena parte del círculo nobiliario en torno a la realeza, era devoto de la Orden de San Jerónimo, hasta el punto de proceder como uno de sus financiadores ${ }^{22}$. Había sufragado su primera fundación, el referido monasterio de San Bartolomé de Lupiana (Guadalajara), y, si cabe con mayor notoriedad, había costeado de su bolsillo un segundo establecimiento en las cercanías de la ciudad del Tajo, el igualmente señalado monasterio de Santa María de la Sisla. Su relación con los jerónimos, en consecuencia, era destacada. Lo que no impidió, sin embargo, que fray Alfonso de Oropesa rechazase el nombramiento.

El marqués de Villena, Enrique de Figueredo y el prior de Santa María de la Sisla acordaron repartirse algunas de las riquezas de Girón: "Çiertas baxillas de oro e de plata, e monedas de oro e piedras presçiosas, e joyas e perlas $»^{23}$. Una parte quedó bajo custodia de los dos primeros, responsables máximos de la gestión de la herencia del difunto, y la otra parte, un auténtico tesoro, se llevó al monasterio de la Sisla, donde quedaría acogido a sagrado. Santa María de la Sisla se convertiría, por esta causa, aunque fuese de manera simbólica, en el sitio más relevante a la hora de cobrar las indemnizaciones que se habían de hacer por los destrozos perpetrados por Girón y sus tropas. No mucho tiempo atrás el maestre había costeado el refectorio y la reforma del primer claustro de la abadía ${ }^{24}$.

${ }^{21}$ AHN, Frías, caja 662, doc. 15 y caja 823, doc. 5. MADRID y MEDINA, 2004: 306-307.

22 LADERO QUESADA, 1986.

${ }^{23}$ OSTOS SALCEDO, 2004: 464-465.

${ }^{24}$ HERGUEDAS VELA, 2017: 101-102. 
CuAdro 2

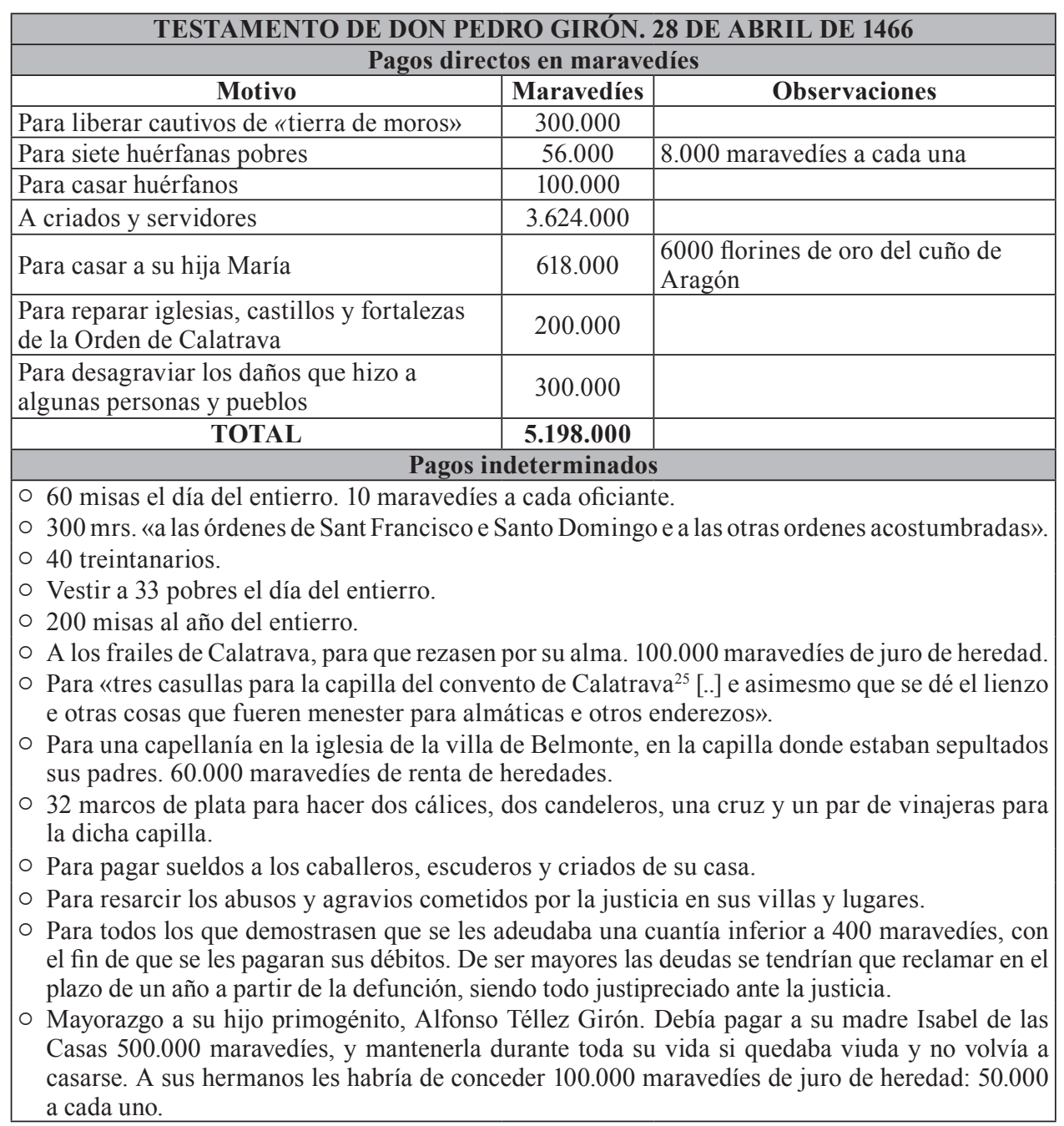

\section{LA INDEMNIZACIÓN POR LOS DAÑOS COMETIDOS (1466-1496)}

Desconocemos el número real de demandas interpuestas por culpa de los perjuicios que habían ocasionado Girón y su ejército. Aunque los testimonios que se

${ }^{25}$ RODRÍGUEZ-PICAVEA MATILLA, 2006: 227-233.

Hispania, 2021, vol. LXXXI, n. ${ }^{\circ}$ 269, septiembre-diciembre, págs. 591-619, ISSN: 0018-2141, e-ISSN: 1988-8368 https://doi.org/10.3989/hispania.2021.014 
conservan son numerosos, no nos han llegado todas las solicitudes, «averiguaçiones y cartas de pago» que hubo. Según Enrique de Figueredo, las cuentas estaban asentadas «en el libro de las dichas satisfaçiones» del escribano Alvar de León ${ }^{26}$; pero a día de hoy no ha aparecido. Además, no todos los atropellos fueron denun$\operatorname{ciados}^{27}$. En ocasiones, ni siquiera personas que servían a los reyes o a la nobleza se enteraron de que estaban efectuándose pagos. Y aunque lo llegaran a conocer, solicitar una compensación a alguien tan poderoso como el conde de Urueña podía resultar no solo complicado, sino incluso contraproducente. Por lo tanto, es lógico que la información que tenemos se refiera primordialmente a individuos cercanos a Girón - comendadores, servidores - y a personas que gozaban de un estatus alto y una posición privilegiada.

Otros obstáculos surgidos a la hora de resolver la cuestión de las indemnizaciones se podrían achacar, en cierto modo, al sistema rigurosamente garantista que establecieron los testamentarios del maestre de Calatrava, en virtud de tres principios: la puesta en duda de toda información que no se pudiera avalar fehacientemente, el cálculo a la baja de cualquier daño producido, y, por último, y a no ser que la suma a sufragar fuera de poca cuantía, el desembolso de las indemnizaciones a través de un doble pago: primero una suma pequeña, en torno al 30 $\% \mathrm{y}$, posteriormente, una cantidad mayor, definitiva, de la que solía encargarse Figueredo, con el objetivo de finiquitar la compensación. Todo se avalaba mediante cartas de pago expedidas a nombre de los albaceas del difunto o de sus apoderados, como fray Rodrigo de Orense, luego prior de la Sisla — sustituto de Mesa - y general de San Bartolomé de Lupiana ${ }^{28}$, o fray Bartolomé de Almodóvar, sacristán del convento-fortaleza de la Orden de Calatrava.

Las circunstancias acaecidas tras la muerte de Girón, a partir de 1466, también iban a dificultar el resarcimiento de los abusos. Ateniéndonos a ellas, podrían distinguirse de forma más o menos clara tres períodos de reparación: uno fundamental, de seis años, entre 1468 y 1474, en el que se pusieron la mayoría de las demandas, y en el que Juan Pacheco fiscalizó las indemnizaciones. Un segundo período más largo e impreciso, que abarcaría el resto de la década de 1470 y la de 1480 , en el que, si bien apenas habría demandas, su importe sería muy elevado. Y, por último, un tercer período, entre 1490 y 1496, en el cual se concluyeron las compensaciones, tras requerirse la mediación del papa Inocencio VIII.

${ }^{26}$ OSTOS SALCEDO, 2004: 464.

${ }^{27}$ Por ejemplo, a Álvaro de Lugo, regidor de Medina del Campo, el maestre le arrebató la escribanía mayor del juzgado de los fieles ejecutores de Sevilla: AGS, RGS, leg. 146712, doc. 9. Se conserva una carta de tutoría para Catalina Álvarez, viuda del bachiller Alfonso Álvarez, vecino de Toledo, que se hizo con el fin de defender a sus hijos en un juicio, posiblemente, sobre asuntos relacionados con los daños producidos por Girón, pero no se sabe más al respecto: AHN, Osuna, caja 2, doc. 38-39 (imágenes 33 a 38).

28 OSTOS SALCEDO, 2004: 463-465. 


\section{Primer período de indemnizaciones (1466-1474). De la muerte de Girón a la muerte de Juan Pacheco}

No parece que en principio hubiera dificultad alguna a la hora de hacer inventario de las posesiones de Pedro Girón, tasarlas y mantenerlas en un lugar seguro. Sin embargo, la sombra de Pacheco planeaba sobre cualquier operación e iniciativa. Aunque resolvió delegar el asunto en Figueredo, excusándose de proceder directamente como albacea, lo fiscalizaba todo desde la lejanía, como era propio de él, requiriendo responsabilidades. Su hermano le había conferido la tarea de servir como tutor de los hijos que había dejado menores de edad, por lo que el marqués recelaba de todo pago que afectase a su herencia. Así parece desprenderse de la primera orden de desembolso que nos ha llegado, datada en el monasterio de Santa María de la Sisla el 16 de septiembre de 1468, a favor de doña Catalina de Guzmán, mujer del comendador Alfonso Suárez Dávila, e hija única y heredera de Francisco de Guzmán, aposentador del Enrique IV. Sus padres, ella y sus gentes habían sido expoliados en un camino tiempo atrás por una tropa de Girón. Les habían quitado todo, causándoles un gravísimo perjuicio. Pero Juan Pacheco dispuso que no se les entregaran más de 20.000 maravedíes. Así que Catalina, aceptándolo, en nombre suyo y de sus padres advirtió que, aun consintiéndose la indemnización, había de quedar a salvo su derecho a recibir un desagravio mayor «sy por aventura el muy magnífico e virtuoso Señor don Iohan Pacheco [...] en algúnd tienpo quesier mandar faser alguna más satisfaçión $»^{29}$.

Las investigaciones y los pagos apenas se detuvieron por el fallecimiento del primer conde de Urueña, Alfonso Téllez Girón, con apenas quince años. El 7 de junio de 1469 el joven realizó su testamento en El Espinar (Segovia) ${ }^{30}$, dejándolo todo en manos de su tío, el marqués de Villena, su madre Isabel de las Casas y Enrique de Figueredo. Dejó por heredero a su hermano Juan Téllez Girón, designándolo segundo conde de Urueña, y pidió a sus albaceas y a dicho conde que se encargaran de «cumplir e executar» lo dispuesto por su padre, fallecido hacía tres años. Por ende, la averiguación de las indemnizaciones fue reanudada.

Catalina de Guzmán presentó nuevos testimonios que acreditaban la incautación que había sufrido. Según ella, un día de septiembre de 1464 su padre, su madre, ella y algunos de sus servidores venían de Aguilafuente a Fuentidueña cuando les acometió «çierta gente de cavallo del magnífico Señor don Pero Girón» que, a la fuerza, les tomaron todo; «fasta nos dexar desnudos a pie en el canpo», advertía Catalina. A fin de acreditar la cuantía del expolio, la deman-

${ }^{29}$ AHN, Osuna, caja 2, docs. 35-37 (imagen 16).

30 AHN, Osuna, caja 105, docs. 21-22. 
dante presentó un inventario con más de sesenta apuntes ${ }^{31}$, donde se señalaban las joyas, ropas, monedas, animales y bienes que había perdido, y se daban detalles de la humillación padecida. Habían sacado a su madre ciertas piezas de oro «del seno», y habían exigido a su padre que les entregara incluso los «borseguíes quel dicho Françisco de Gusmán levava calçados $\rangle^{32}$. En su defensa, Catalina consiguió que testificasen cinco criados del maestre que habían intervenido en el robo, o que sabían de lo acontecido, los cuales, en efecto, aseguraron que la incautación había sido total. Según dijeron, el maestre, por entonces enfrentado al rey Enrique IV, se dirigía a Andalucía, y, como dudaba de las intenciones de sus enemigos, había adelantado a una avanzadilla «a descobrir tierra e a tajar los caminos». Cuando los rastreadores se toparon con el padre de la demandante y resolvieron que era alguien próximo al monarca, no hubo dudas a la hora de acometer. Más tarde, ya con el botín en sus manos, Girón dividió las ganancias en tres porciones: una se la quedó él, la otra la repartió entre las personas que estimó oportunas, y el resto fue entregado a los hombres que habían intervenido en el atraco. La repartición de los bienes entre estos, no obstante, generó problemas, hasta el punto de que algunos llegaron a las manos. Y, al final, se pactó hacer varias almonedas en distintas poblaciones - Tordelaguna, Pedraza, Yepes - , para dividir lo incautado entre los salteadores, siempre a precios por debajo de su valor real ${ }^{33}$. El montante de lo que se pujó apenas llegaría a los 60.000 maravedíes, cuando debería haber valido el doble ${ }^{34}$.

A tenor de estos testimonios, se acordó dar a Catalina de Guzmán una segunda carta de pago de 50.000 maravedíes, el 3 de febrero de $1470^{35}$, a sumar a los 20.000 concedidos en 1468. Cinco días más tarde, el 8 de febrero, también se concedió una carta de pago de 5.000 maravedíes a Fernando de Valencia, uno de los criados del maestre a quien Catalina había presentado como testigo, que, aprovechándose de tener que dar testimonio, reclamó una compensación por tres caballos de los que su señor le había desposeído ${ }^{36}$.

Juana González, por su parte, viuda del bachiller Alvar González, pidió en Almagro, el 25 de febrero de 1470, que se tomara declaración al cura de la villa, Juan Ruiz Nieto, para que aclarase cuáles habían sido las palabras que su esposo había dicho al sacerdote cuestionando la autoridad de Girón, por las que este había ordenado que se le confiscara toda su hacienda ${ }^{37}$. Unos días después, el 1

31 AHN, Osuna, caja 2, docs. 35-37 (imágenes 3 y 4). Copia moderna en AHN, Osuna, caja 2, docs. 38-39 (imágenes 38 a 43). Memorial publicado en UHAGÓN, 1898, doc. X: 95-98.

32 AHN, Osuna, caja 2, docs. 35-37 (imagen 5).

33 AHN, Osuna, caja 2, docs. 35-37 (imagen 4).

34 AHN, Osuna, caja 2, docs. 35-37 (imagen 5).

${ }_{35}$ AHN, Osuna, caja 2, docs. 35-37 (imagen 6).

${ }^{36}$ AHN, Osuna, caja 2, docs. 38-39 (imágenes 64 a 67) y caja 3, doc. 74.

${ }_{37}$ AHN, Osuna, caja 2, docs. 38-39 (imágenes 2 y 3). Copia moderna en AHN, Osuna, caja 2, docs. 38-39 (imágenes 32 y 33). 
de marzo, en Ocaña, Juana presentaría dicho testimonio a Figueredo, junto con otras dos testificaciones y una relación minuciosa de los bienes expropiados ${ }^{38}$. Pese a todo, no se sabe en qué deparó su denuncia, al no existir más informaciones. La siguiente carta de pago de la que hay noticia, del 5 de abril de 1470, es a nombre de Fernán López, un boticario al que sufragaron 3.000 maravedíes en concepto de medicinas impagadas ${ }^{39}$.

Al margen de estos cobros particulares, al año siguiente, en 1471, se costearon «los dapnos que se fizieron en el Campo de Calatrava, en el tienpo de la guerra que se fiso contra el clavero e contra Çibdad Real, a las personas a quien fueron fechos». Se trataba del primer gran desembolso - el de mayor cuantía, y el que a más víctimas alcanzaba - de cuantos se habían efectuado hasta entonces.

Enrique de Figueredo solicitó a Bartolomé de Almodóvar, sacristán del convento-fortaleza de Calatrava, que se encargase de desagraviar a quienes pidieran algún tipo de compensación en el territorio de la orden. Para tal fin, se llevó a cabo una investigación por la que se concluyó que cuarenta y una personas o familias habían experimentado pérdidas, residentes en seis localidades del Campo de Calatrava: Almagro, Aldea del Rey, Carrión, Malagón, Miguelturra y Piedrabuena. El perjuicio estimado ascendía a 889.035 maravedíes, si bien Figueredo únicamente realizó un libramiento de 148.092 a fray Bartolomé de Almodóvar, que se costeó en dos pagos. El primero, de 33.950 maravedíes, el día 22 de agosto de 1471 - Diego Gutiérrez de Almagro dio el dinero a Luis de Olid, sobrino y apoderado de fray Bartolomé-, y un segundo desembolso el 31 de agosto, de $114.142^{40}$. Las razones de esta rebaja en la estima no se señalan, pero parecen obedecer a una confrontación de estrategias: la de las víctimas que habían sufrido los daños, que hicieron lo posible para que se los apreciasen al alza, y la de fray Bartolomé y Figueredo, que, por contra, tasaron todo a la baja, hasta tal punto que su desagravio no llegó ni al $17 \%$ de lo requerido.

Fray Bartolomé comenzó a indemnizar a las víctimas de manera inmediata, «por mandado del Señor maestre de Santiago». Incluso antes de recibir el segundo desembolso, ya realizó las dos primeras liquidaciones de 8.000 y 1.750 maravedíes a sendos vecinos de Almagro, a quienes realmente habían tasado las pérdidas sufridas en 61.110 y 5.000 maravedíes. En ocasiones, la diferencia entre lo solicitado y lo que se concedió sería formidable. Por ejemplo, en el caso de Juan Sánchez, vecino de Almagro, la estima alcanzaba los 80.000 maravedíes, pero tan solo se le pagaron 1.500. Y algo similar ocurrió con Juan García

38 AHN, Osuna, caja 2, docs. 38-39 (imágenes 4 a 11). Copia moderna en AHN, Osuna, caja 2, docs. 38-39 (imágenes 58 a 63). VIÑA BRITO, 1988, tomo II, doc. 28: 143-153. AGUADO GONZÁLEZ, 1991: 180-183.

39 AHN, Osuna, caja 3, doc. 22.

40 AHN, Osuna, caja 2, doc. 40 (imagen 5). 
Sobrino, vecino de Carrión, al que, habiéndosele apreciado sus daños en 86.500 maravedíes, cobró $9.000^{41}$. Los casos más llamativos serían los de Piedrabuena, cuyo concejo había apreciado las pérdidas que había sufrido en 106.630 maravedíes, si bien solo recibió 20.000; y el del alcaide Nuño Fernández de Villalvi1lo, vecino de Aldea del Rey, que solo logró 10.000 maravedíes, cuando había reclamado un total de $98.000^{42}$.

\section{CuAdro 3}

\begin{tabular}{|c|c|c|c|c|c|c|c|c|c|c|}
\hline \multicolumn{11}{|c|}{ DESEMBOLSO QUE SE HIZO POR LOS DAÑOS EN EL CAMPO DE CALATRAVA } \\
\hline & \multirow[b]{2}{*}{ 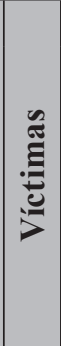 } & \multirow[b]{2}{*}{ 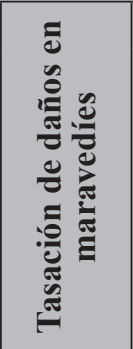 } & \multirow[b]{2}{*}{ 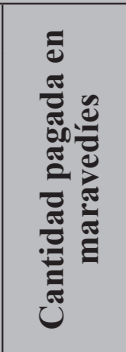 } & \multicolumn{7}{|c|}{ Forma de pago real, en monedas de la época } \\
\hline & & & & 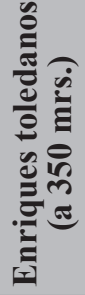 & 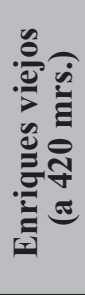 & 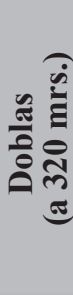 & 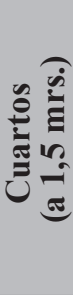 & 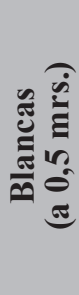 & 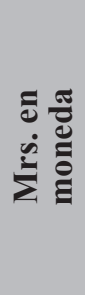 & 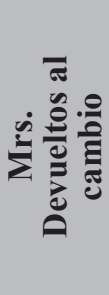 \\
\hline CARGO & & & 148.092 & & & & & & & \\
\hline $\begin{array}{l}\text { F. Bartolomé } \\
\text { de Almodóvar }\end{array}$ & & & 148.092 & 285 & 115 & & 28 & 3 & & \\
\hline DATA & & 889.035 & 145.400 & & & & & & & \\
\hline Aldea del Rey & 9 & 189.020 & 23.550 & 66,5 & 0 & 0 & 0 & 0 & 425 & -150 \\
\hline Almagro & 18 & 366.320 & 54.400 & 89,5 & 55,5 & 0 & 0 & 0 & 240 & -475 \\
\hline Carrión & 8 & 173.520 & 34.050 & 97 & 0 & 0 & 0 & 0 & 300 & -150 \\
\hline Malagón & 4 & 45.595 & 8.400 & 24 & 0 & 0 & 0 & 0 & 0 & 0 \\
\hline Miguelturra & 1 & 7.950 & 5.000 & & 12 & & & & & -40 \\
\hline Piedrabuena & 1 & 106.630 & 20.000 & 57 & & & & & 50 & \\
\hline $\begin{array}{c}\text { Otros (pago } \\
\text { de escribano) }\end{array}$ & & & 2.000 & & 4 & 1 & & & & \\
\hline Total & 41 & 889.035 & 145.400 & 334 & 71,5 & 1 & $\mathbf{0}$ & $\mathbf{0}$ & 1.015 & -815 \\
\hline ALCANCE & & & 2.692 & & & & & & & \\
\hline
\end{tabular}

$\mathrm{Si}$ es que hubo quejas ante semejantes depreciaciones, como seguramente así fue, no nos han llegado. En cada uno de los desembolsos del memorial de desagravio se refirió la siguiente fórmula, por la que quienes recibían el dinero quedaban comprometidos, a fin de invalidar una futura reclamación:

... remitió e perdonó el demás, et otorgó carta de pago e de fyn e quito al ánima del Señor maestre et a sus herederos e testamentarios.

${ }^{41}$ AHN, Osuna, caja 2, doc. 40 (imagen 7).

${ }^{42}$ AHN, Osuna, caja 2, doc. 40 (imagen 8). 
Por las fechas en que se producía la indemnización al Campo de Calatrava también se llevaban a cabo averiguaciones más al norte, en la villa de Torrijos. Aquí no se trataba de un territorio, sino de una localidad que había recibido un trato «extremadamente duro» por parte de Girón ${ }^{43}$, al parecer por dos razones: como castigo por su supuesto apoyo a su adversario Alfonso de Aragón cuando este, en su contra, había sido designado maestre de Calatrava, en 1450 —un asunto por el que también se atacó a la villa de Ocaña—44; y por la necesidad que por aquel entonces Pedro Girón tenía de un botín, ya que, habiendo sido designado alcaide de Toledo por el príncipe Enrique (luego Enrique IV) para acabar con la revuelta de la urbe en contra de Juan II, había críticas por los bienes que se había llevado su predecesor en el oficio, el famoso Pero Sarmiento, cuando se le echó de la metrópoli45. El maestre/alcaide necesitaba riquezas para comprar voluntades, con el fin de someter al común toledano.

Según los testimonios que más tarde darían personas que habían estado presentes $^{46}$, Girón fue a Torrijos en noviembre de 1450 con una tropa de seis mil hombres: «Gente de cavallo e peones, e lançeros e vallesteros». Servidores suyos y vecinos tanto «de su tierra como de la dicha çibdad de Toledo» ${ }^{47}$, a las órdenes de cuatro capitanes ${ }^{48}$ : Pedro Ramírez de Guzmán, Pedro de los Ríos, Diego Palomeque y Diego Muñoz, comendador mayor de las Casas. Cuando en Torrijos se supo que se acercaba una muchedumbre de combatientes se cerraron las puertas de la muralla, y algunos de sus habitantes decidieron buscar refugio en la parroquia de San Gil, metiendo en ella algunas de sus posesiones, pensando que el invasor no se atrevería a violar el recinto sagrado.

Una vez con el ejército ante la villa, el asedio duró poco. La muralla era de escasa calidad ${ }^{49}$, así que, en breve, fueron destruidos algunos de sus lienzos, y se quemaron sus puertas. Se inició entonces un expolio sistemático: calle por calle y casa por casa. Los que se opusieron a los saqueadores fueron liquidados, y se acordó prender fuego a la iglesia, para obligar a salir a los que estaban dentro, que, inmediatamente, se rendirían.

Ante una población indefensa y desamparada, el robo duró varios días. Incontables carromatos partieron a Toledo con bienes de todo tipo: joyas, cereales, vino, ropa, aceite, muebles. Los saqueadores se llevaron todo el ganado de la villa - mulas, gallinas, ovejas, caballos, vacas - . Algunas viviendas quedaron completamente despojadas, y se secuestró a las personas más ricas, para

${ }^{43}$ FRANCO SILVA, 1995: 234.

44 PÉREZ DE GUZMÁN, año 1451, cap. IV: 552.

45 LÓPEZ GÓMEZ, 2017.

${ }^{46}$ Testimonios posteriores aseguran que fue el 5 de noviembre, pero la referencia parece errónea: RUIZ SOLANO, 1978: 92.

47 AHN, Osuna, caja 2, docs. 35-37 (imagen 12).

48 AHN, Osuna, caja 2, docs. 35-37 (imagen 12).

49 MOLENAT, 1997: 536. 
solicitar un rescate. Como conclusión de la campaña, unos días después la tropa de Girón atacó y expolió el castillo de Canales. Y luego marchó sobre Ocaña, villa que, si bien fue «aportillada» como advertencia, no fue «acometida a sacomano».

Transcurridos más de veinte años desde que sucedieran estos hechos, los albaceas de Pedro Girón recabaron informaciones para resarcirlos. En virtud de ello, el primer pago a la villa de Torrijos se produjo a finales de 1470, o posiblemente ya en 1471, y ascendió a 126.400 maravedíes. Como solía ser habitual en la liquidación de grandes sumas, se realizó en dos plazos: primero, fray Alfonso de Mesa entregó 26.400 maravedíes a Ferrand Flores, procurador del concejo y, más tarde, fray Juan de Toro, también fraile de la Sisla, en nombre de Figueredo, pagó otros 100.000.

En la primavera de 1473 tuvo lugar un segundo desembolso. Al parecer Torrijos era uno de los lugares más perjudicados por las acciones de Girón. El 21 de marzo se llamó a los vecinos «a conçejo, por son de canpana tañida, a la casa de Santa María», un edificio de la catedral de Toledo, y allí, con los «alcaldes, alguasil, regidores, jurados e procurador e ofiçiales e omes buenos» al frente, y con un auditorio nutrido, con «mugeres e niños e niñas, que y estavan ${ }^{50}$, se explicaron las razones de la asamblea y, en nombre de todo el concejo, se suscribió una nueva carta de pago a los testamentarios del difunto por 111.137,5 maravedíes, que, al sumarse a la cantidad que se había recibido en el abono anterior, daba una liquidación total de 237.537,5 maravedíes; una cifra mucho mayor que la establecida para resarcir al Campo de Calatrava.

Quien se encargó de hacer las gestiones fue fray Rodrigo de Orense, entonces ya prior del monasterio de la Sisla, que, en nombre de Figueredo, dio al procurador Ferrand Flores los dichos 111.137,5 maravedíes $^{51}$ :

... en un barril grande de plata dorado de peso de treynta e dos marcos e çinco honças e quatro reales, contados e apresçiados por ofiçiales plateros, a razón de a dies doblas de oro castellanas de la vanda cada marco.

Como después de tantos años era difícil evaluar el daño sufrido por cada persona, los albaceas de Girón acordaron ofrecer el «barril grande de plata» en compensación para el concejo en su conjunto; algo que permitiría bajar las tributaciones particulares o hacer una obra pública. El problema era que no todos los que residían en la población formaban parte de su concejo: solamente los «vesinos moradores e pecheros», es decir, las personas que, albergando su vecindad en Torrijos, vivían y tributaban allí, lo que excluía, de facto, a los no pecheros — nobles y religiosos - , a los no residentes y, de forma expresa, «a

${ }^{50}$ AHN, Osuna, caja 2, docs. 35-37 (imagen 12).

51 AHN, Osuna, caja 2, docs. 35-37 (imagen 13). 
los moradores della vesinos de la dicha çibdad de Toledo», quienes, además de no contribuir con la hacienda local, eran de la urbe cuyos habitantes habían asaltado la villa.

Semejante forma de proceder en el desembolso indudablemente haría que surgieran rumores y un cierto malestar, pero la información que nos ha llegado es muy limitada. La familia que, por los datos que tenemos, se mostró más en contra fue la de la difunta doña Mencía Rodríguez, liderada por sus hijos Alfonso Rodríguez, vecino de Toledo, y Pedro de Torrijos ${ }^{52}$. Este último, a esas alturas - a mediados de los 70 del siglo XV - se encontraba en el entorno de la princesa Isabel, quien, ya reina, le nombraría contador de su despensa y racionero de su casa ${ }^{53}$. Fue dicha proximidad a la corte, no en vano, lo que le permitió dirigirse a Juan Pacheco para que mediara en la cuestión del robo sufrido por los suyos.

El marqués de Villena, haciéndose eco de la solicitud de Pedro de Torrijos, mandó una carta al prior del monasterio de la Sisla para que viera el caso ${ }^{54}$. Y este, en respuesta, diputó a uno de sus monjes, para que aclarase «la verdad de las cosas que en esta dicha villa fueron tomadas et robadas a Pedro de Torrijos e a su madre et fermanos». El 14 de diciembre de 1473 el monje sometió a una batería de seis preguntas a cuatro testigos que el demandante había presentado $^{55}$. Según sus testimonios, en 1450, en medio del saqueo, una horda de treinta individuos había entrado en la casa de doña Mencía, una de las dueñas más ricas del lugar. Un hombre que les hizo frente, el casero Juan García, fue asesinado, y se lo llevaron todo; incluidas las cerraduras de las puertas ${ }^{56}$. No quedó «salvo algún pan derramado por la casa e cámaras, e [...] la bodega llena de vino, que lo avían dejado verter de las cubas». Más tarde, al dividir «çierta plata e oro et aljófar, et bestias e ropas de vestir, e otras cosas, se quisyeron matar» los referidos treinta individuos - el reparto de los expolios asiduamente generaba disturbios, como también se vio en el caso de Catalina de Guzmán-. El perjuicio fue tal que doña Mencía, «asaz pobre», hubo de marcharse de la población con su familia. Y como su hijo Alfonso era mayordomo del arzobispo de Toledo, y este consideraba que en el saqueo había perdido parte de sus rentas, ocupó sus heredades durante cuatro años, hasta que, en 1455, permitió que doña Mencía las vendiera, para que «le pagasen lo que asý les avían robado». Solo de esta forma la familia de Pedro de Torrijos logró

${ }^{52}$ AHN, Osuna, caja 2, docs. 38-39 (imágenes 21 a 28). Copia moderna en AHN, Osuna, caja 2, docs. 38-39 (imágenes 50 a 57).

53 AGS, RGS, leg. 147702, doc. 306. Había conseguido el título de escribano en 1475, AGS, RGS, leg. 147506, doc. 490. También se le nombró mozo de cámara, AGS, Cámara de Castilla, cédulas 9 , doc. 111,1 .

${ }^{54}$ AHN, Osuna, caja 2, docs. 38-39 (imágenes 21-22).

55 AHN, Osuna, caja 2, docs. 38-39 (imágenes 22-23).

56 AHN, Osuna, caja 2, docs. 38-39 (imagen 27). 
recuperar unos 300.000 maravedíes $^{57}$, que, permitiéndoles salir a flote, harían que, sin embargo, fuera dudosa la solicitud de compensaciones que se presentó a los albaceas de Girón veinte años más tarde, porque, aunque indirectamente, el expolio ya estaba resarcido.

\section{Segundo período de indemnizaciones (1475-década de 1480). De la guerra entre Juana e Isabel a la defunción de Figueredo}

Según las informaciones conservadas, cuando el marqués de Villena falleció, en el mes de octubre de 1474, los testamentarios de Girón ya habían sufragado en concepto de indemnizaciones un total de 611.029,5 maravedíes; más del doble de lo estipulado en su testamento ${ }^{58}$. Esta circunstancia, unida a la guerra que iba a producirse tras la muerte de Enrique IV, hizo que se dejaran de realizar pagos.

Como es bien sabido, el sucesor de Juan Pacheco, su hijo Diego López, se posicionó del lado de Juana en la guerra con Isabel; y lo mismo hicieron sus dos primos: Rodrigo Téllez Girón, maestre de Calatrava ${ }^{59}$, y Juan Téllez Girón, conde de Urueña, responsable de hacer cumplir la voluntad de su padre como heredero de su mayorazgo. Este último y su canciller Figueredo eran los que, desde hacía años, se encargaban de la custodia de la reina y de su hija Juana ${ }^{60}$, de modo que iban a desempeñar un rol muy destacado en los primeros compases de la conflagración ${ }^{61}$.

Teniéndolos por adversarios, Isabel ordenó que se expropiaran los cargos públicos de Enrique de Figueredo ${ }^{62}$ y, el 24 de mayo de 1475, acusó a los hijos de Girón de cometer un delito de lesa majestad, exigiendo, por ende, que perdieran todos sus títulos señoriales y nobiliarios, que se incautaran sus propiedades, que sus vasallos quedaran libres de todo voto de obediencia y pleito homenaje, que nadie les ofreciese salvaguarda o auxilio y, por último, que sus deudores no les amortizasen cantidad alguna ${ }^{63}$. Se trataba de medidas en verdad drásticas, que, no obstante, apenas se llevaron a efecto, porque la postura

57 AHN, Osuna, caja 2, docs. 38-39 (imagen 26).

58 Curiosamente, una cantidad parecida a la que el marqués de Villena estableció en su propio testamento en concepto de reparación de daños: MADRID y MEDINA, 2004: 306-307.

59 HERAS, 2008: 199-205. RODRÍGUEZ-PICAVEA MATILLA, 2006: 203-204.

${ }^{60}$ AHN, Frías, caja 16, docs. 25 y 26.

${ }^{61}$ Se conserva una carta escrita por el propio Figueredo en 1474 recomendado la entrada del rey de Portugal en Castilla: AHN, Frías, caja 127, doc. 9.

${ }^{62}$ En 1475 Isabel privó a Figueredo de la escribanía de las rentas del Principado de Asturias (AGS, RGS, leg. 147508, doc. 580 y leg. 147512, doc. 762) y de un regimiento en León (AGS, RGS, leg.147510, doc. 64.

${ }^{63}$ AHN, Osuna, caja 279, doc. 14. 
de Juan y de Rodrigo se doblegó pronto, y, tras cambiar de bando, en 1476 fueron perdonados por Isabel ${ }^{64}$, y se les restituyeron sus títulos y sus posesiones ${ }^{65}$, lo mismo que a sus hombres ${ }^{66}$. Aun así, la guerra continuaba. Y, a pesar de haberse revocado, la disposición de 1475 crearía un cierto caos, sirviendo de excusa a los que tenían deudas con el conde de Urueña, para no pagárselas ${ }^{67}$, y a este, de igual modo, para suspender toda compensación por los abusos cometidos en otros tiempos.

Concluida la guerra, la problemática en torno a las últimas voluntades del maestre de Calatrava de nuevo adquirió protagonismo, según los datos que se han conservado. En 1480, con el fin de congraciarse con Juan Téllez Girón, Juan Arias Dávila, obispo de Ávila, perdonó el reembolso de «cualquier pan, trigo e çeuada e çenteno» que su padre le hubiera robado «en el logar de Lagunillas» ${ }^{68}$. Pedro de Torrijos, por el contrario, continuó reclamando una indemnización de 300.000 maravedíes - aunque aseveraba que lo justo serían $800.000^{69}$ —. Y, finalmente, logró que le entregasen 150.000 , si bien en «çiertas pieças de oro que en la Sysla estavan» de tan penosa calidad que en absoluto tenían ese valor ${ }^{70}$. Gómez Fernández, otro vecino de Torrijos, también consiguió que le sufragaran 140.000 maravedíes, a inicios de la década de 1480. Primero 90.000, y luego 50.000. En este caso en dos pagos, en bienes que también se custodiaban en la Sisla: 30.000 en monedas y en dos «copones de plata dorados», y 20.000 en un salero ${ }^{71}$.

Por aquellos años, en la primera mitad de los 80 del siglo XV, las solicitudes de indemnización se mezclaban con los requerimientos del conde Urueña a los deudores y antiguos mayordomos de su padre, para que le liquidaran lo que le debían ${ }^{72}$. El hastío por los obstáculos económicos heredados del maestre comenzaba a resultar muy palpable. Y, en esta situación, dos factores iban a hacer que el escenario se tornara aún más difícil. En primer lugar, una denuncia interpuesta en 1484 , que amenazaba con resultar muy gravosa. La había realizado un caballero vecino de Toledo, Antón de Luna, cuya familia había sido despojada de sus bienes en Torrijos en 1450, perdiendo, según decía, 750.000 maravedíes; que «non dexaron cosa ninguna» en su vivienda ${ }^{73}$. Por

${ }^{64}$ AHN, Osuna, caja 3, docs. 24-24. TORRES-FONTES SUÁREZ, 1977: 50-55.

${ }^{65}$ AHN, Osuna, caja 3, docs. 9, 10, 11-15 y 33-37. AHN, Osuna, caja 35 docs. 90 y 91. AHN, Frías, caja 1512, doc. 18 y caja 1444, doc. 2.

${ }^{66}$ Caso de Figueredo: AGS, RGS, leg. 147610, doc. 642 y leg. 147611, doc. 701.

67 AGS, RGS, leg. 147706, doc. 271.

${ }_{68}$ AHN, Osuna, caja 3, doc. 75.

${ }^{69}$ AHN, Osuna, caja 2, doc. 41-43 (imagen 12).

70 AHN, Osuna, caja 2, doc. 41-43 (imagen 13).

71 AHN, Osuna, caja 2, docs. 41-43 (imágenes 3 y 4).

72 AGS, RGS, leg. 148310, docs. 30, 31 y 32. AHN, Osuna, caja 41, doc. 43.

73 AHN, Osuna, caja 2, docs. 38-39 (imágenes 13 a 19). 
otra parte, la salud de Figueredo no era la de antaño. El canciller hizo su testamento el 24 de mayo de 1486, afirmando, entre otras cuestiones, que por culpa de la «guerra y los bolliçios y escándalos acaesçidos» no había podido resarcir todos los abusos realizados por Pedro Girón, y que, por tal causa, para descargo de su propia conciencia y de su ánima, «e en hemienda de la negligençia [...] por non aver distribuydo los dichos bienes en el dicho tienpo que podiera e deuiera», dejaba 100.000 maravedíes al prior de la Sisla $^{74}$, para que continuase con el desagravio de las injusticias auspiciadas por el antiguo maestre.

\section{Tercer período de indemnizaciones (década de 1490). La solución de Giovanni Battista Caccialupi y el fin de los pagos}

Casi veinticinco años después de la muerte de Girón, su voluntad de reparo de daños seguía comprometiendo a sus herederos. La demanda de Antón de Luna aparentemente era la más problemática, pero seguían llegando al Consejo Real toda clase de solicitudes de resarcimiento por los desórdenes acaecidos ${ }^{75}$, y era previsible que el asunto continuara causando dificultades. De modo que Juan Téllez Girón, dispuesto a hacer cualquier cosa para impedirlo, decidió solicitar ayuda a la Santa Sede, con vistas a conseguir algún tipo de dispensa que lo liberara de tener que continuar cumpliendo las últimas voluntades de su padre.

En una fecha que no se indica, probablemente en 1489 o ya en la primera mitad de 1490, el conde de Urueña consiguió que sus demandas quedasen en manos de Giovanni Battista Caccialupi (1420-1496), un célebre jurisconsulto italiano, que había sido profesor en la Universidad de Siena y que, desde hacía tiempo, trabajaba en Roma como abogado consistorial y escritor al servicio de los papas. Oriundo de San Severino Marche, también era conde, en su caso de Truschia. Escritor prolijo, se había hecho famoso en 1467 por la publicación de una obra titulada Modus studendi in utroque iure, un bestseller de la época entre los estudiantes de derecho ${ }^{76}$.

Se conservan dos copias del «responsum» que Caccialupi realizó al requerimiento de Téllez Girón ${ }^{77}$. El jurisconsulto redactó un memorial no muy largo - cinco páginas en la copia más antigua - en un latín farragoso, lleno de abreviaturas y de citas a autores y a tratados. Autores entre los que, como era

74 OSTOS SALCEDO, 2004: 452.

75 A Íñigo de Pedrola, vecino de Baeza, el maestre le tomó una casa, y la dio en merced: AGS, RGS, leg. 148709, leg. 128. Alonso García tuvo que abandonar Arjonilla por su enfrentamiento con Girón, y se hizo entrega de sus bienes a otra persona: AGS, RGS, leg. 148906, doc. 76

${ }^{76}$ GENTILI, 1844. BENAVENTE, 1972. MAFFEI, 1997. ASCHERI, 2000. FRIGERIO, 2004. CACCIALUPI, 2019.

77 AHN, Osuna, caja 2, docs. 41-43 (imágenes 5 a 8). AHN, Osuna, caja 1523, doc. 56. 
habitual en él, destacarían San Agustín, Santo Tomás de Aquino y Bartolomé de Sassoferrato.

En el prólogo, Caccialupi empezaba invocando a Cristo antes de advertir que, con reverencia, se disponía a tratar el asunto sobre el que se le había pedido asesoramiento, dada la carga que padecía la conciencia del conde de Urueña - «quae respiciunt onus non leue conscientiae»-, confiando en que la clemencia divina le guiaría en su cometido ${ }^{78}$. A partir de ahí, el memorial se dividía en cuatro argumentaciones. En la primera, la más espaciosa, el erudito reflexionaba sobre las conflagraciones, bullicios y altercados en que se había visto envuelto Pedro Girón. Según él, deberían enmarcarse en un contexto de guerra justa - «bellum iustum»- y de crisis política ${ }^{79}$, donde el maestre de Calatrava, por obediencia a su rey o por otras legítimas razones, había tenido que combatir contra enemigos del monarca y contra ciudadanos insurrectos — «rebelles Serenissimo Regi et hostes eius tunc»—. Girón había cumplido las órdenes de su señor y había respetado los usos tradicionales de la guerra en cuanto a los métodos de lucha y al reparto de botín, de forma que, a priori, nada podía imputársele. No había violencia, coerción ni saqueo cuando, por obediencia a un rey, o por motivos justificados, no por avaricia ni por ansias de poder, se atacaba a los enemigos y a los malhechores - «contra hostes pugnando vel contra cives malefactores puniendo»-. Por lo tanto, según Caccialupi, el maestre no tenía por qué haber incluido entre sus últimas voluntades una cláusula de reparación por lo que había hecho ${ }^{80}$.

Partiendo de esta tesis, el erudito italiano aseveraba que, aunque el maestre hubiera pecado - «siquidem dictus Magister militiae fuisset reus peccati»-, el deber de restituir los bienes usurpados en los conflictos no era suyo, ni, en consecuencia, tampoco de sus herederos. No había que entrar en discusiones en torno a su posible perversidad- «animo culposo et anbitioso»-, por más que los remordimientos le hubieran llevado a buscar el indulto desagraviando a sus víctimas ${ }^{81}$. La obligación de resarcir los agravios cometidos no tenía por qué aparecer en el testamento de Girón. Sin embargo, continuaba Caccialupi, a pesar de todo, el maestre había pedido un resarcimiento en sus mandas testamentarias ${ }^{82}$, lo que, en virtud del derecho canónico, obligaba a sus sucesores a cumplirlo, como si se tratase de una sentencia o de un contrato — «quasi contractu uel ex setentia»—- ${ }^{83}$. Así que, dictami-

78 AHN, Osuna, caja 2, docs. 41-43 (imagen 6).

79 Sobre el concepto «guerra justa», véase: GRASSOTTI, 1976. VALLS I TABERNER, 1988. LORA SERRANO, 1991. HAGGENMACHER, 1992. BARKAI, 2007. BAQUÉS QUESADA, 2007. LÓPEZ BARJA DE QUIROGA, 2011.

${ }^{80}$ AHN, Osuna, caja 2, docs. 41-43 (imágenes 6 y 7).

81 AHN, Osuna, caja 2, docs. 41-43 (imágenes 7 y 8).

82 AHN, Osuna, caja 2, docs. 41-43 (imágenes 7 y 8).

${ }^{83}$ AHN, Osuna, caja 2, docs. 41-43 (imagen 8). 
naba el jurisconsulto, no había más solución que acatar el testamento, a no ser que se recurriera a determinado subterfugio teológico y jurídico que en opinión de Giovanni Battista Caccialupi era el único posible, y que, a la postre, sería el planteado por el conde de Urueña: requerir al papa que suspendiese la ejecución de las últimas voluntades del maestre de Calatrava a cambio del pago de una indulgencia definitiva, alegándose que no era posible conocer a qué personas concretas se debía indemnizar.

De este modo, en función de lo que había determinado el jurisconsulto pontificio, Inocencio VIII promulgó una bula, el 31 de julio de 1490, en la que se exoneraba al conde de Urueña de tener que cumplir el testamento de su padre en el asunto de los daños que había producido, y se daba por nula toda solicitud de compensación que en adelante se interpusiera, a no ser que fuese admitida por un juez autorizado ${ }^{84}$. A cambio, Juan Téllez Girón debía sufragar una indemnización última: 2.000 ducados de oro. 1.500 —en torno a 560.000 maravedíes - a «las comunidades y universidades» de Toledo, Ciudad Real, Jaén y Torrijos, para obras pías, o en beneficio de «todos los çibdadanos y moradores». Y 500 - unos 187.000 maravedíes - en penitencia, por los daños sufridos por aquellas personas de las que no hubiese noticia, para «reparaçión del hedifiçio de la Sacra Verónica o sudario de nuestro Señor Ihesu Christo en la iglesia de Sant Pedro de Roma». Mediante estos desembolsos, absuelta el alma de Girón y exonerados sus sucesores, únicamente la justicia podría exigir que se realizase una nueva compensación.

Sobre el pago de los 2.000 ducados de oro se conserva otro escrito, también en latín, en el que Juan Téllez Girón ordena que se ejecute, copiando frases de la bula que lo había establecido ${ }^{85}$. Aun así, y aunque es posible que se conserve, no hemos hallado ningún finiquito. En todo caso, el efecto que tuvo con inmediatez lo que determinó el papa fue el que perseguía el conde: anular que se ejecutase indemnización alguna. Por ejemplo, Rodrigo de Alarcón, un vecino de Vélez, había logrado una cédula del Consejo Real para que se le realizara un segundo desembolso por la toma de 4.000 cabezas de ganado, tras los 28.000 maravedíes que ya había recibido ${ }^{86}$. Empero, en función de la bula de Inocencio VIII y de lo argumentado por Caccialupi, se rechazó su solicitud, afirmándose que el robo había ocurrido en tiempos de «guerras guerreadas, y por mandado del señor Rey don Enrrique, seyendo prínçipe» ${ }^{87}$.

${ }^{84}$ Se conservan varias copias, en latín y castellano: AHN, Osuna, carpeta 60, doc. 13. AHN, Osuna, caja 3, docs. 61-63 (imágenes 6 a 8 y 11 y 12).

${ }^{85}$ AHN, Osuna, caja 2, docs. 41-43 (imagen 9).

${ }^{86}$ AGS, RGS, leg. 149008, doc. 349.

${ }^{87}$ AHN, Osuna, caja 3, doc. 72 (imagen 4). AGS, RGS, leg. 149009, doc. 119. 


\section{Cuadro 4}

\begin{tabular}{|c|c|c|c|c|}
\hline \multicolumn{5}{|c|}{$\begin{array}{l}\text { INDEMNIZACIONES POR LOS DAÑOS Y ABUSOS } \\
\text { COMETIDOS POR DON PEDRO GIRÓN (1466-1496) }\end{array}$} \\
\hline Beneficiario & $\begin{array}{c}\text { Cantidad } \\
\text { solicitada } \\
\text { en mrs. }\end{array}$ & Año & $\begin{array}{c}\text { Cantidad } \\
\text { indemnizada } \\
\text { en mrs. }\end{array}$ & Año \\
\hline Almagro & 366.320 & 1471 & 202.492 & 1471 \\
\hline Carrión & 173.520 & 1471 & 34.050 & 1471 \\
\hline La Aldea del Rey & 189.020 & 1471 & 23.550 & 1471 \\
\hline Malagón & 45.595 & 1471 & 8.400 & 1471 \\
\hline Miguelturra & 7.950 & 1471 & 5.000 & 1471 \\
\hline Piedrabuena & 106.630 & 1471 & 20.000 & 1471 \\
\hline Otros (pago de escribanos) & & 1471 & 2.000 & 1471 \\
\hline Campo de Calatrava. Total & 889.035 & 1471 & 295.492 & 1471 \\
\hline Concejo (primer pago) & & & 126.400 & $1470 ?$ \\
\hline Concejo (segundo pago) & & & $111.137,5$ & 1473 \\
\hline Gómez Fernández (primer pago) & & & 90.000 & 1468 \\
\hline Gómez Fernández (segundo pago) & & & 50.000 & 1481 \\
\hline Pedro de Torrijos & 800.000 & 1473 & $150.000^{*}$ & $1481 ?$ \\
\hline Antón de Luna & 750.000 & 1484 & 150.000 & 1496 \\
\hline Villa de Torrijos. Total & & & 677537,5 & \\
\hline Juana González, vecina de Almagro & & 1470 & ¿? & ¿? \\
\hline Catalina de Guzmán (primer pago) & & & 20.000 & 1468 \\
\hline Catalina de Guzmán (segundo pago) & & & 50.000 & 1470 \\
\hline Obispo de Segovia & & & Perdona saqueo & 1480 \\
\hline Fernán López, boticario & & & 3.000 & 1470 \\
\hline Fernando de Valencia, criado & & & 5.000 & 1470 \\
\hline Rodrigo de Alarcón, vecino de Vélez & & & 28.000 & $1470 ?$ \\
\hline Denuncias particulares. Total & & & 106.000 & \\
\hline Ciudad de Jaén & & & 260.000 & 1494 \\
\hline Bula. A Toledo, Jaén, Torrijos y Ciudad Real & & & 562.500 & 1490 \\
\hline Bula. Para obra de San Pedro & & & 187.500 & 1490 \\
\hline Bula de Inocencio VIII. Total & 750.000 & 1490 & $750.000 * *$ & 1490 \\
\hline $\begin{array}{c}\text { TOTAL } \\
\end{array}$ & & & $2.089 .029,5$ & \\
\hline
\end{tabular}

* Según AGUADO GONZÁLEZ, 1991: 168, los hijos de doña Mencía recibieron 300.000 maravedíes, si bien no hemos hallado huella documental al respecto. A Pedro de Torrijos le pagaron 150.000 maravedíes de mala calidad. No obstante, su familia había cobrado, en efecto, 300.000 de la venta de sus bienes raíces.

** Se contabiliza el ducado de oro a 375 maravedíes.

Sin la presión de tener que indemnizar los abusos perpetrados por su padre, el conde de Urueña se preocupó en 1492 por no recibir pérdidas económicas a 
causa del destierro de los judíos, algunos de los cuales le eran deudores ${ }^{88}$. Y más tarde, en 1494, cumpliendo lo establecido por el papa, concedió a Jaén 260.000 maravedíes para construir un depósito de cereal, que habría de permanecer constantemente abastecido, para que la población no pasara hambre ${ }^{89}$. Por entonces, siempre según la documentación que tenemos, el único asunto por resolver era el de Antón de Luna, a cuyas demandas Téllez Girón se había negado a contestar. El 15 de marzo de 1494, Luna logró que los reyes exigieran al conde que le pagara lo que le requería o que, de lo contrario, acudiese ante la justicia a defender su derecho, como estipulaba la bula de Inocencio VIII ${ }^{90}$. Esto dio lugar a un largo juicio en la Chancillería de Valladolid, que, por fortuna para el demandante, concluyó con una sentencia a su favor, a pesar de que el conde de Urueña había defendido, nuevamente siguiendo a Caccialupi, que en 1450 la familia de Antón de Luna era adversaria de la Corona, a la que servía su padre. El 20 de septiembre de 1496 la Chancillería expidió una ejecutoria para que se pagasen los 150.000 maravedíes que Luna solicitaba ${ }^{91}$. Por lo que sabemos, sería la última liquidación fruto de la violencia y los latrocinios de Pedro Girón, aunque tampoco se conserva finiquito ni carta de pago. Se producía 30 años después de la muerte del maestre, haciendo que, en total, contando con los 2.000 ducados de oro de la bula, la cantidad resarcida por sus arbitrariedades hubiese ascendido a nada menos que casi 2.100 .000 maravedíes, seis veces más que lo estipulado en su testamento.

\section{CONCLUSión GENERAL}

Es dudoso que el conde de Urueña realizara más indemnizaciones, una vez se pagó a Antón de Luna lo requerido por la Chancillería de Valladolid. Años después, en 1502, Juan Téllez cumplió una de las últimas disposiciones aún no aplicadas del testamento de su padre: la dotación de una capellanía en la iglesia colegial de la villa de Belmonte, en donde estaban enterrados sus abuelos, para que allí se celebraran misas por su salvación eterna ${ }^{92}$. Era el acto que ponía

88 AGS, RGS, leg. 149212, doc. 111.

89 AGS, RGS, leg. 149403, doc. 4. Se ha conservado una abundante y sugestiva documentación acerca del establecimiento del referido depósito de trigo en Jaén. A cambio de su constitución, el Ayuntamiento de la ciudad y la gente de sus parroquias hubo de conceder un perdón colectivo y público al antiguo maestre de Calatrava, habiendo pasado ya casi treinta años desde su fallecimiento. Véase esta documentación en: AHN, Osuna, caja 35, exp. 103. Los datos contenidos en estos documentos permiten un estudio exhaustivo sobre la población de Jaén: PORRAS ARBOLEDAS, 1991.

90 AGS, RGS, leg. 149403, doc. 452.

91 ARChV, Registro de ejecutorias, caja. 104, doc. 10.

92 AHN, Osuna, caja 35, doc. 12. 
punto final a lo requerido por Pedro Girón en sus últimas voluntades. De todo ello, lo concerniente al resarcimiento de los menoscabos de los que había sido responsable se había convertido, sin duda, en la cuestión más espinosa. Numerosos factores habían hecho que, al llevarse a la práctica, surgieran obstáculos de toda especie, convirtiendo el asunto en un auténtico quebradero de cabeza, en la medida en que, al margen de las averiguaciones realizadas, siempre se podía poner en cuestión lo apropiado de las compensaciones a realizar.

Las intenciones fraudulentas y la mala memoria podían jugar malas pasadas y, por eso, sistemáticamente se desembolsaron sumas de maravedíes inferiores a las requeridas. Además, como hemos visto, múltiples circunstancias harían que nunca fueran fáciles las indemnizaciones: la fiscalización de Juan Pacheco, la muerte del primer conde de Urueña, el apoyo del segundo conde a la causa de Juana en la guerra con Isabel, las deudas debidas a este último. Las suspicacias iban in crescendo según pasaban los años y las solicitudes de compensación seguían produciéndose. Y a ello se sumaba el problema moral de tener que efectuar unos pagos que, aunque por el alma de Pedro Girón, se dudaba si eran justos, pues se había excedido sobremanera la cantidad estipulada por el maestre en su testamento para este fin.

Como se ha señalado, fue el jurisconsulto Giovanni Battista Caccialupi quien dio una solución viable ante semejante problemática, en un memorial firmado como «Baptista Carrialupus, de Sancto Seuerino aduocatus consistorialis». Dicha obra fue el paso previo a la concesión de una bula que, finalmente, liberaría a los herederos de Girón de acarrear con el póstumo arrepentimiento de un hombre al que, de manera merecida o no, la historia ha venido considerando uno de los grandes villanos de su época.

\section{Bibliografía}

Aguado González, Francisco Javier, El ascenso de un linaje castellano en la segunda mitad del siglo XV: los Téllez Girón, condes de Urueña (el origen del señorío de Osuna), tesis doctoral inédita, Madrid, Universidad Complutense, 1991.

Ascheri, Mario, «Essay G. B. Caccialupi (1420 - ca. 1496) fautore dei Monte di Pietà», en Richard Henry Geburtstag Helmholz, Paul Mikat, John Müller y Michael Stolleis (eds.), Grundlagen des Rechts. Festschrift für Peter Landau, Paderborn, Universidad de Paderborn, 2000: 643-654.

Atienza Hernández, Ignacio, Aristocracia, poder y riqueza en la España Moderna. La Casa de Osuna, siglos XV-XIX, Madrid, Siglo XXI, 1987.

Baqués Quesada, Josep, La teoría de la guerra justa. Una propuesta de sistematización del «ius ad bellum», Pamplona, Thompson-Aranzadi, 2007.

Barkai, Ron, El enemigo en el espejo. Cristianos y musulmanes en la España medieval, Madrid, Rialp, 2007. 
Barrientos, Lope de, Refundición de la crónica del Halconero de Juan II, edición de Juan de Mata Carriazo y Arroquia, Madrid, Espasa-Calpe, 1946.

Benavente, Juan Alfonso de, Ars et doctrina studendi et docendi, edición crítica y estudio por Bernardo Alonso Rodríguez, Salamanca, Universidad Pontificia de Salamanca, 1972.

Benito Ruano, Eloy, Toledo en el siglo XV. Vida política, Madrid, CSIC, 1961.

Cabrera, Emilio, «En torno a una enconada rivalidad por el Maestrazgo de Calatrava durante el siglo XV», Espacio, Tiempo y Forma. Serie III Historia Medieval, 1 (Madrid, 1989): 75-96.

Cabrera, Emilio, «El maestrazgo de Calatrava, objeto de disputa entre los Guzmán y los Girón durante el siglo XV», en Ricardo Izquierdo Benito y Francisco Ruiz Gómez (eds.), Las órdenes militares en la Península Ibérica, Ciudad Real, Junta de Comunidades de Castilla-La Mancha / Fundación Quijote, IV Centenario, 2007: 7-30.

Caccialupi, Giovanni Battista, «De debitoribus suspectis et fugitivis de Giovanni Battista Caccialupi», Anuario de derecho concursal, 46 (Madrid, 2019): 145-199.

Carrillo de Huete, Pedro, Crónica del Halconero de Juan II, edición de Juan de Mata Carriazo y Arroquia, Madrid, Espasa-Calpe, 1946.

Ciudad Ruiz, Manuel, «El maestrazgo de Don Rodrigo Téllez Girón», En la España medieval, 23 (Madrid, 2000): 321-365.

Cooper, Edward, Castillos señoriales en la Corona de Castilla, Salamanca, Junta de Castilla y León, 1991.

Crónica de Enrique IV, edición de Antonio Paz y Melia, Madrid, Atlas, 1973-1975, 3 vols. Biblioteca de Autores Españoles, tomos 257-258 y 267. [1. a ed. 1904-1909].

Diago Hernando, Máximo, «Conflictos violentos en el seno de las oligarquías de las ciudades castellanas a fines de la Edad Media: los "bandos" de Ávila», ejemplar dedicado a: Nobleza bajomedieval en Castilla, Studia historica. Historia medieval, 34 (Salamanca, 2016): 297-320.

Enríquez del Castillo, Diego, Crónica de Enrique IV, edición de Aurelio Sánchez Martín, Valladolid, Universidad de Valladolid, 1994.

Fernández de Larrea y Rojas, Jon Andoni, «Nobles violentos. Malhechores feudales. Lucha de bandos»), en Esther López Ojeda (coord.), La violencia en la sociedad medieval, Nájera, 23 a 27 de julio de 2018, Logroño, Instituto de Estudios Riojanos, 2019: 117-131.

Franco Silva, Alfonso, «Don Pedro Girón, fundador de la casa de Osuna (1423-1446)», en Manuel García Fernández y Juan José Iglesias Rodríguez (coords.), Osuna entre los tiempos medievales y modernos (siglos XIII-XVIII), Sevilla, 1995: 63-94.

Franco Silva, Alfonso, Juan Pacheco, privado de Enrique IV de Castilla. La pasión por la riqueza y el poder, Granada, Universidad de Granada, Sevilla y Cádiz, 2011.

Frigerio, Alessandra, «Umanesimo del diritto: il "De modo in iure studendi" di Giovanni Battista Caccialupi, 1464», Annali dell'Istituto storico italo-germanico in Trento, 30 (Trento, 2004): 35-48.

Galíndez de Carvajal, Lorenzo, Crónica de Enrique IV, edición de Juan Torres Fontes, Murcia, CSIC / Universidad de Murcia, 1946. 
Gentili, Giovanni Carlo, Elogio di Giovanni Battista Caccialupi dè conti della Truschia giureconsulto ed avvocato concistoriale del secolo XV, Macerata, Editorial Mancini, 1844.

González Sánchez, Santiago, La alta nobleza castellana a comienzos del siglo XV. Consolidación de linajes y casas nobles, Madrid, Dykinson / Comité Español de Ciencias Históricas / Fundación Cultural de la Nobleza Española y Real Cuerpo de la Nobleza de Madrid, 2018.

Grassotti, Hilda, «El deber y el derecho de hacer guerra y paz en León y Castilla», Cuadernos de Historia de España, LIX-LX (Buenos Aires, 1976): 221-296.

Haggenmacher, Peter, «Guerra justa y guerra legítima en la doctrina española del siglo XVI», Revista Internacional de la Cruz Roja-Cambridge, 17 (Cambridge, 1992): 459-471.

Heras, Jesús de las, La Orden de Calatrava. Religión, guerra y negocio, Madrid / México / Buenos Aires / San Juan / Santiago / Miami, Edaf, 2008.

Herguedas Vela, Miguel, Patronazgo real en los monasterios jerónimos de la Corona de Castilla: arte y arquitectura, Valladolid, Universidad de Valladolid, 2017, https://www. educacion.gob.es/teseo/imprimirFicheroTesis.do?idFichero $=$ vGVGm91B1FY\%3D.

Jara Fuente, José Antonio, «El conflicto en la ciudad: violencia política en la Castilla urbana del siglo XV», en Esther López Ojeda (coord.), La violencia en la sociedad medieval, Nájera, 23 a 27 de julio de 2018, Logroño, Instituto de Estudios Riojanos, 2019: 85-115.

Ladero Quesada, Miguel Ángel, «Mecenazgo real y nobiliario en monasterios españoles: los jerónimos (siglos XV y XVI)», ejemplar Homenaje a José María Lacarra, Príncipe de Viana. Anejo, 2-3 (Pamplona, 1986): 409-440.

Lop Otín, María José y López Gómez, Óscar, «Entre la paz y el caos. Acción subversiva y actividad pacificadora en las élites urbanas. Toledo, 1441-1495», Hispania: Revista española de historia, 75/250 (Madrid, 2015): 413-440.

López Barja de Quiroga, Pedro Manuel, «Sobre la guerra justa», Semata: Ciencias sociais e humanidades, 23 (Lisboa, 2011): 61-76.

López Gómez, Óscar, «Élites urbanas y conflictividad social. Una reflexión a partir del caso de Toledo en el siglo XV», ejemplar dedicado a: Historia de las emociones, Vinculos de Historia, 4 (Ciudad Real, 2015): 228-250.

López Gómez, Óscar, «El saqueo de la villa de Torrijos. Nuevos datos sobre la rebelión de 1449 en Toledo», De Medio Aevo, 11/1 (Madrid, 2017): 13-42.

Lora Serrano, Gloria, «La organización de la defensa militar de un estado señorial y el potencial bélico de un noble a mediados del siglo XV», Historia. Instituciones. Documentos, 18 (Sevilla, 1991): 297-338

Madrid y Medina, Ángela, «Los otros dos hermanos, maestres tan prosperados como reyes», Anales de la Real Academia Matritense de Heráldica y Genealogía. Homenaje a Don Faustino Menéndez Pidal, VIIII/2 (Madrid, 2004): 539-555.

Maffei, Domenico, "Giovan Battista Caccialupi biografo», Zeitschrift der SavignyStiftung für Rechtsgeschichte: Kanonistische Abteilung, 83 (Berlín, 1997): 392-400.

Molenat, Jean Pierre, Campagnes et Monts de tolède du XII au XVe siècle, Madrid, Casa de Velázquez, 1997. 
Monsalvo Antón, José María, «Violence Between Factions in Medieval Salamanca. Some Problems of Interpretation», Imago temporis. Medium Aevum, III (Lleida, 2009): 139-170.

Monsalvo Antón, José María, «Relaciones entre nobleza y monarquía en el siglo XV: faccionalismo y acción política de los Álvarez de Toledo (Casa de Alba)», ejemplar dedicado a: Nobleza bajomedieval en Castilla, Studia historica. Historia medieval, 34 (Salamanca, 2016): 149-185.

Moreta Velayos, Salustiano, Malhechores-feudales. Violencia, antagonismos y alianzas de clases en Castilla, siglos XIII-XIV, Madrid, Cátedra, 1978.

Narbona Vizcaíno, Rafael, «Vida política y conflictividad urbana en los reinos hispánicos (siglos XIV-XV)», en Las sociedades urbanas en la España medieval. XXIX Semana de estudios medievales, Estella, 15-19 julio 2002, Pamplona, Gobierno de Navarra / Universidad de Navarra, 2003: 541-589.

O'Callaghan, Joseph F., «Don Pedro Girón, Master of the Order of Calatrava, 14451446», Hispania. Revista Española de Historia, LXXXIII (Madrid, 1961): 342-390.

O'Callaghan, Joseph F., The Spanish Military Order of Calatrava and its Affiliates, Londres, Variorum Reprints, 1975.

Ostos Salcedo, Pilar, «Enrique de Figueredo, ¿canciller de la Orden de Calatrava?», Historia. Instituciones. Documentos, 31 (Sevilla, 2004): 451-473.

Otero Piñeyro Maseda, Pablo S. y García-Fernández, Miguel, «Los testamentos como fuente para la historia social de la nobleza. Un ejemplo metodológico: tres mandas de los Valladares del siglo XV», Cuaderno de Estudios Gallegos, LX/126 (Santiago de Compostela, enero-diciembre 2013): 125-149.

Palencia, Alonso de, Crónica de Enrique IV escrita en latín, Antonio Paz y Melia (trad.), Madrid, Tipografía de la Revista de Archivos, 1904.

Pérez de Guzmán, Fernando, Crónica del señor don Juan, segundo de este nombre en Castilla y en León. Corregida, enmendada y adicionada por Lorenzo Galíndez de Carvajal, Valencia, Imprenta de Benito Monfort, 1779.

Pérez de Guzmán, Fernando, Crónica de Juan II de Castilla, edición de Juan de Mata Carriazo y Arroquia, Madrid, Real Academia de la Historia, 1982.

Plaza Pedroche, Milagros, «La Orden de Calatrava en la Baja Edad Media (1350-1500): repaso historiográfico», Espacio, tiempo y forma, Serie III. Historia medieval, 31 (Madrid, 2018): 575-596.

Porras Alboledas, Pedro A., «La población de la ciudad de Jaén a fines de la Edad Media (1476-1500)», Boletín del Instituto de Estudios Gienneses, CXLIV (Jaén, 1991): 53-114.

Porro, Nelly Raquel, «Consideraciones en torno a una carta de legitimación», Cuadernos de Historia de España, 37/38 (Buenos Aires, 1963): 346-355.

Rodríguez-Picavea Matilla, Enrique, «Mentalidad, cultura y representación del poder de la nobleza calatrava en la Castilla del siglo XV», Hispania. Revista Española de Historia, LXVI/222 (Madrid, enero-abril 2006): 199-242.

Rodríguez-Picavea Matilla, Enrique, «El proceso de aristocratización de la Orden de Calatrava (siglos XIII-XV)», Hispania Sacra, LIX/120 (Madrid, julio-diciembre 2007a): 493-535. 
Rodríguez-Picavea Matilla, Enrique, «Caballería y nobleza en la Orden de Calatrava: Castilla, 1350-1450», Anuario de Estudios Medievales, 37/2 (Barcelona, juliodiciembre 2007b): 711-739.

Solano Ruiz, Emma, La Orden de Calatrava en el siglo XV. Los señoríos castellanos de la orden al fin de la Edad Media, Sevilla, Universidad de Sevilla, 1978.

Solórzano Telechea, Jesús, «Violencia y conflictividad política en el siglo XV: el delito al servicio de la élite en las Cuatro Villas de la Costa de la Mar», Anuario de Estudios Medievales, 35/1 (Barcelona, 2005): 159-184.

Torres-Fontes Suárez, Cristina, «Don Rodrigo Téllez Girón, maestre de Calatrava», Miscelánea Medieval Murciana, III (Murcia, 1977): 41-71.

Uhagón, Francisco Rafael de, Órdenes militares. Discursos leídos ante la real Academia de Historia en la recepción pública del Excmo. Señor D. Francisco R. de Uhagón, el día 25 de marzo de 1898, Madrid, Viuda e Hijos de Tello, impresor de Cámara de S.M., 1898.

Uhagón, Francisco Rafael de, «Índice de los documentos de la Orden Militar de Calatrava existentes en el Archivo Histórico Nacional», Boletín de la Real Academia de la Historia, XXV (Madrid, julio-septiembre 1899). Puede consultarse copia online en: http://www.mcu.es/ccbae/es/consulta/registro.cmd?id=214293.

Val Valdivieso, María Isabel del, «Relaciones de don Pedro Girón, maestre de Calatrava, con el rey don Enrique IV», en VII Centenario del Infante don Fernando de la Cerda. Jornadas de Estudio. Ciudad Real, abril de 1975, Ciudad Real, Instituto de Estudios Manchegos, 1976: 159-170.

Valls i Taberner, Ferran, «El problema de la licitud de la guerra segons Sant Ramon de Penyafort», Cuadernos informativos de derecho histórico público, procesal y de la navegación, 8 (Barcelona, 1988): 921-930.

Villegas Díaz, Luis R., «Las estructuras de poder de la Orden de Calatrava. Una propuesta de análisis», Historia. Instituciones. Documentos, 18 (Sevilla, 1991): 467-504.

Viña Brito, Ana, Los orígenes del señorio de Osuna, Tenerife, Universidad de La Laguna / E.T.D. Microfichas, 1988.

Viña Brito, Ana, «Testamento de don Pedro Girón», Anuario de Estudios Medievales, 19 (Barcelona, 1989): 493-505.

Viña Brito, Ana, «Don pedro Girón y los orígenes del señorío de Osuna», Historia. Instituciones. Documentos, 17 (Sevilla, 1990): 267-285.

Recibido: 20/02/2020

Aceptado: 17/11/2020 